Review

\title{
Geoengineering in the Anthropocene through Regenerative Urbanism
}

\author{
Giles Thomson * and Peter Newman \\ Curtin University Sustainability Policy Institute, Curtin University, Perth 6102, WA, Australia; \\ P.Newman@curtin.edu.au \\ * Correspondence: Giles.Thomson@curtin.edu.au; Tel.: +61-8-9266-9030 \\ Academic Editors: Carlos Alves and Jesus Martinez-Frias
}

Received: 26 June 2016; Accepted: 13 October 2016; Published: 25 October 2016

\begin{abstract}
Human consumption patterns exceed planetary boundaries and stress on the biosphere can be expected to worsen. The recent "Paris Agreement" (COP21) represents a major international attempt to address risk associated with climate change through rapid decarbonisation. The mechanisms for implementation are yet to be determined and, while various large-scale geoengineering projects have been proposed, we argue a better solution may lie in cities. Large-scale green urbanism in cities and their bioregions would offer benefits commensurate to alternative geoengineering proposals, but this integrated approach carries less risk and has additional, multiple, social and economic benefits in addition to a reduction of urban ecological footprint. However, the key to success will require policy writers and city makers to deliver at scale and to high urban sustainability performance benchmarks. To better define urban sustainability performance, we describe three horizons of green urbanism: green design, that seeks to improve upon conventional development; sustainable development, that is the first step toward a net zero impact; and the emerging concept of regenerative urbanism, that enables biosphere repair. Examples of green urbanism exist that utilize technology and design to optimize urban metabolism and deliver net positive sustainability performance. If mainstreamed, regenerative approaches can make urban development a major urban geoengineering force, while simultaneously introducing life-affirming co-benefits to burgeoning cities.
\end{abstract}

Keywords: sustainable cities; Anthropocene; Paris Agreement; COP21; regenerative design; green urbanism; urban geoengineering

\section{Introduction}

\subsection{The Anthropocene}

The impact of humans upon the biosphere is leaving a pervasive and persistent signature on Earth. This human geologic agency is the basis of proposals for a new geologic epoch — the Anthropocene [1-3]. This agency differs from all previous epochs in that human awareness provides this epoch with a "consciousness". It is this intentional anthropogenic agency in relation to environmental impact, upon which this article focuses. If negative Anthropogenic impact results from previous conscious decision making by humans, so it follows, that conscious decisions can also steer the planetary future away from the existential risks as outlined by the Intergovernmental Panel on Climate Change (IPCC) [4], to shape a positive outcome for the Anthropocene. However, there has not yet been a clear idea of how this can be done. This paper outlines how cities can harness their positive potential to regenerate the Anthropocene [5]. Cities lie at the nexus of environmental impact, mitigation and governance and as such represent an important target if one wishes to make a big impact on sustainability. Since the majority of the world's growing population is urban, and urbanizing [6], city regions are the frontier 
of future environmental impact, they can also become the arena best suited for mitigating this impact. This will be given focus by understanding the changes to urban metabolism that must be engendered to enable such a radical change in human history.

\subsection{High Level Governance of Anthropogenic Climate Change}

Anthropogenic climate change is well documented, having been the subject of mainstream science for around three decades $[7,8]$. As humanity tracks, monitors and recognizes the increasingly adverse environmental impacts and risks related to greenhouse gas (GHG) emissions [9] the urgency to act is becoming a powerful political agenda [10-12].

The last decade has seen a rapid rise in mainstream environmental consciousness and this is beginning to permeate national and international policy. Significant steps have been taken toward forging international agreements, most significantly with the announcement of the Paris Agreement (COP21) in December 2015 [13]. The objective of the agreement is to build momentum toward neutralizing the risk of climate change through stabilization or mitigation of GHG emissions. Mitigation, as defined by the IPCC, is a human intervention to reduce the sources or enhance the sinks of GHG [14].

The Paris Agreement is the first universal global climate deal (signed by 195 countries). It commits signatory nations to "aggregate emission pathways consistent with holding the increase in the global average temperature to well below $2{ }^{\circ} \mathrm{C}$ above preindustrial levels and pursuing efforts to limit the temperature increase to $1.5^{\circ} \mathrm{C}$ above preindustrial levels" [13]. Increasing risks of climate inaction are outlined by the IPCC [15] with this in turn driving an increased urgency to consciously manipulate the planetary climate in the Anthropocene [14]. The Paris Agreement, while requiring emission reductions, does not explicitly provide pathways for achieving its goals. The details are the domain of each sovereign state to determine, but undoubtedly this commitment will require large scale socio-technical transformation [16-18]. The current path dependent lock-in of a hydrocarbon fuelled economy is well documented (see [19-21]). The smooth transition to a low carbon economy will be very difficult due to the high resistance to change typical of path dependence $[16,18,22]$. Climate change is a "wicked problem" [23] highly resistant to resolution due to complex interconnections between institutions and infrastructures of current conventional production processes and products. Resistance to change is further confounded by entrenched cultural values and assumptions that involve marketing, social groups, policy makers who provide regulatory frameworks, industry associations and various associated networks [24]. As a result of these mutual dependencies the tendency is for incremental change along predictable trajectories [17]. However, what is needed, and indeed what the Paris Agreement calls for, is wide-scale disruptive innovation to current systems of production, to ensure that atmospheric $\mathrm{CO}_{2} \mathrm{eq}$ is kept below 450 ppm by 2100 to reduce the risk of severe climate change [4]. The Agreement mandates rapid change but what is needed are the tools for large-scale mitigation.

\subsection{Geoengineering: The Silver Bullet?}

The need for large-scale rapid decarbonization has driven investigations into a simple "silver bullet" for climate change mitigation. This has led to proposals for geoengineering [25,26]: the "deliberate, large-scale intervention in the Earth's natural systems to counteract global warming" [27]. Geoengineering approaches can be divided into two major classes, "carbon dioxide removal" (CDR) and "solar radiation management" (SRM) (alternatively known as "albedo management") $[14,26,28]$. Where CDR actively mitigates, SRM is largely used to reflect solar radiation and in this sense is proposed more as a temporary management tool for extreme events.

The IPCC working group III on Mitigation of Climate Change accepted that in the face of extreme climate events the need to quickly offset warming may be required [14]. The report goes on to warn that terrestrial geoengineering techniques would require large scale land use changes, involving local and regional risks, while ocean based techniques (such as iron fertilization) would involve "significant transboundary risks for ocean ecosystems". Similar risks also exist for solar radiation management 
(SRM) which, involves reflective particles or aerosols in the upper atmosphere [14]. The IPCC report highlights questions around "costs, risks, governance, and ethical implications" relating to SRM in particular. These ethical issues were the focus of the "Oxford Principles" developed in 2011 "to provide a code of conduct for geoengineering research" [27]. In addition to environmental risks, the Oxford Principles identified "social risks", for example, "geoengineering research as an excuse to delay reducing emissions" and "knowledge risks" for example "risks that arise from what would happen if we were not able to undertake such research" (i.e., ignorance of the possible techniques that may avert an existential threat to society) [27]. The underlying risks outlined by the Oxford Principles are varied in nature and include practical, ethical and governance concerns.

Similar findings were published in a technical evaluation of impacts report by the US National Academy of Science in 2015, which stated that "climate intervention (geoengineering) is no substitute for reductions in carbon emissions and adaptation efforts aimed at reducing the negative consequences of climate change" [28]. Conventional geoengineering brings with it uncertainty related to unknown or unexpected outcomes in global ecological systems that could threaten the survival of human and other life.

In light of this uncertainty (ethical and governance as much as technical), we suggest city-centric urban geoengineering in lieu of conventional geoengineering approaches. This approach builds upon Fink's suggestions for geoengineering cities to stabilize climate [5], and would incorporate Flannery's "third way" CDR technologies [29]. Third way technologies "recreate, enhance or restore the processes that created the balance of GHG, which existed prior to human interference, with the aim of drawing carbon, at scale, out of the Earth's atmosphere and/or oceans" [29]. Flannery is looking for plants and minerals that can achieve this. Combining urban geoengineering with third way technologies, it is possible to bring the solution back into the heart of human habitats and the generator of most GHG emissions-the city. Coupling rapid climate change mitigation with low carbon urban growth will accelerate CDR processes and may avoid the need for temporary geoengineering measures such as SRM. Focusing upon the urban environment as the arena for change will reduce potential environmental risks to remote geographies such as unproductive land, the atmosphere or the sea, that are typically identified for geoengineering actions.

\section{The Potential of Cities}

\subsection{The Phenomenal Growth of Cities}

Population growth during the Twentieth Century increased threefold, while global market activity increased 50 fold, representing a 16 fold per capita increase in consumption [30]. Most of this increase in wealth can be attributed to the dramatic growth in city population from around 220 million urban dwellers in 1900 to 2.84 billion in 2000 [31]. By 2014, 54\% of the world's population were residing in cities and by 2050 this figure is expected to be close to $70 \%$; and with this increasing urbanization "sustainable development challenges will be increasingly concentrated in cities" [6]. Humans have become an "urban species".

Per capita consumption rates of energy [32,33], and many other resources [34], are typically lower for people living in higher density areas than their suburban or rural counterparts, but room exists for far greater improvements. Redesigning urban environments to drastically reduce per capita consumption has the potential to play a central role in reducing GHG emissions either through the provision of more efficient infrastructure, or, infrastructure that influences more efficient behaviour [35].

To accommodate the projected urban population growth of 2.5 billion people to 2050 from now [6], it will be necessary to build as much new urban infrastructure as existed globally in 1950, but instead of developing over centuries, this infrastructure will need to be built in a little over three decades (see Figure 1, based upon United Nations global growth projections [36]). 


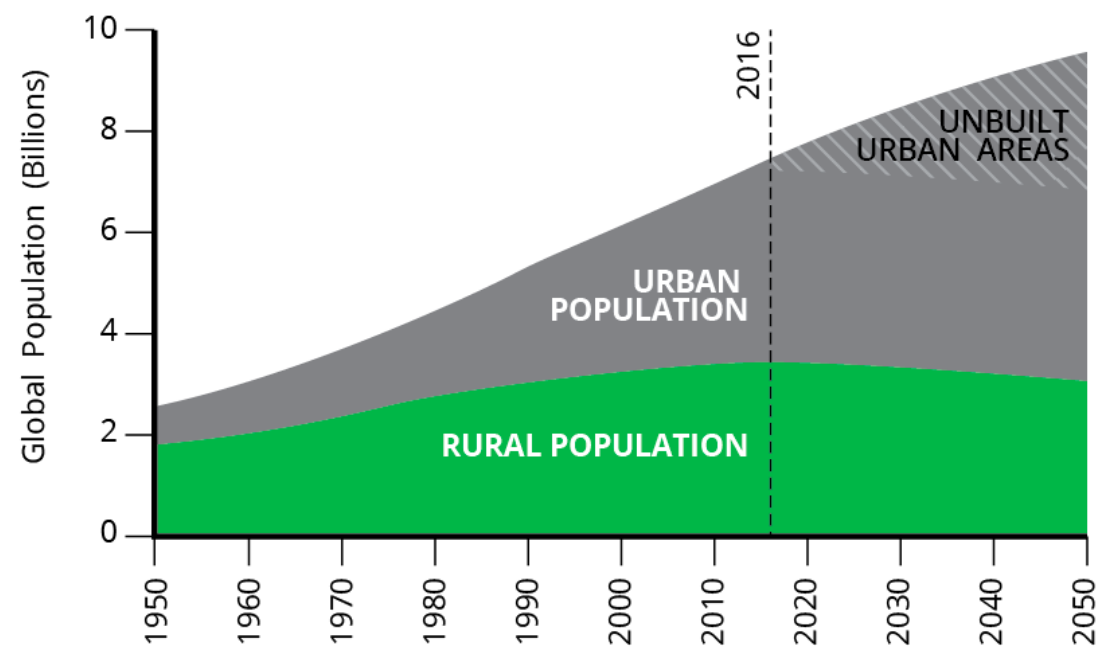

Figure 1. Urbanization population projections and unbuilt urban areas.

In addition to newly constructed urban areas, large existing urban areas will need to be redeveloped including, urban upgrades for the estimated 880 million urban dwellers living in slums and informal settlements [37], and urban renewal areas in developed cities experiencing growth. Redevelopment and renewal of these existing urban areas adds significantly to the global scale of city building over the coming decades. By way of example, Australia's modern and highly liveable cities, were among the fastest growing in the OECD in 2015. They have grown by $25 \%$ since 2000 [38], and the growth from 2016 to 2060 is projected to be another $40 \%$ [38]. Of this growth, $70 \%$ is projected to occur in the capital cities and every major city's long term planning policy has set targets for around $50 \%-70 \%$ infill development (i.e., redevelopment within existing urban areas). Meeting these infill policies will see large areas of Australia's existing, but relatively unsustainable urban fabric, undergo large scale renewal and rebuilding [39].

Opportunity for low carbon urban infrastructure can then be found in:

- cities and urban areas yet to be built;

- urban upgrades in slums;

- urban renewal in growing developed cities;

- urban retrofits of existing areas [40].

It is the unprecedented scale and rate of urban growth and renewal that presents both the challenge and the opportunity. Harnessing this massive urban growth to deliver sustainable cities has the potential to both reduce carbon and repair the biosphere, while also meeting multiple global goals (e.g., the United Nations Sustainable Development Goals [41]).

Innovators in the built environment sector are already demonstrating how green urbanism can radically reduce carbon emissions, while maintaining or even enhancing liveability [35,42-44]. Rapid urbanization presents an opportunity for cities to emerge as an environmental solution as opposed to generators of environmental problems, as long as they adapt to this historic task through strong leadership driving a powerful green urbanism as outlined below. This is the premise behind Sustainable Development Goal 11 "to make cities inclusive, safe, resilient and sustainable" and adopted by 193 nations in 2016. It is the rationale for international organizations such as C40 Cities [45] and ICLEI [46] that have had a strong sustainable city agenda for some time and for the creation of international standards such as ISO 37120:2014-Sustainable development of communities-Indicators for city services and quality of life [47], and ISO 37101:2016(E) Sustainable Development in Communities-Management system for sustainable development [48]. These organizations, goals and standards are all aimed at influencing behavior and outcomes. What is still missing in most jurisdictions is a mechanism to raise revenue for 
agencies responsible for overseeing urban processes to invest in and monitor sustainability measures. For emissions, this might take the form of a local carbon tax or other rate based income stream to provide payments to the various responsible agencies to help facilitate the required transition.

\subsection{Urban Geoengineering and Green Urbanism}

As described earlier, carefully planned urban development may provide infrastructure that helps cities decarbonize; through emission reduction, energy efficiency and third way technologies, which collectively perform an urban geoengineering function. The large decarbonizing potential of cities is only just beginning to be understood. Human settlements in the process of delivering necessary infrastructure to house a rapidly growing population can play an integral role in decarbonizing the planet [21,49-51].

However, global warming is just one of several planetary boundaries currently being transgressed. The potential for a genuinely "green urbanism" by cities and their bioregions, can go further than decarbonizing alone to help address several other planetary limits including land-system change, freshwater use, biodiversity integrity, and biochemical flows of Phosphorus and Nitrogen among others [52-54]. It is the integrated approach of green urbanism that addresses other planetary boundaries while providing habitat for humans that makes the large scale decarbonizing of cities preferable to other geoengineering approaches.

To perform an effective urban geoengineering function, urban development will need to go beyond net-zero (i.e., offsetting all embodied and operational carbon) to become net-positive $[55,56]$. This may be achieved through the creation of cities that are very efficient in terms of operational and embodied energy, and that allow the generation of more energy than is consumed over urban infrastructure lifecycles through the extensive use of renewable energy sources [57]. An example of this is the Solarsiedlung city block of 'plus energy' houses in Freiburg, Germany [58]. Only a coordinated and holistic approach to urban development with an emphasis on third way technologies and integrated urban design can achieve this, and only strong governance at all levels, especially the urban scale, can co-ordinate this $[35,42,59]$. The approach, as outlined below, is being called "regenerative urbanism".

Governance of a regenerative urban system that initiates urban geoengineering, will require measuring and monitoring of sustainability performance. Urban sustainability performance can be analyzed through a material and substance flow analysis [60,61]. Mapping the flow of resources through the city is a well-established, if underutilized, process usually described as urban metabolism [62-65]. Urban metabolism modeling provides a tool for understanding, monitoring and designing the performance of urban systems, not just in terms of GHG emissions, but also broader sustainability elements including renewables, water, waste, transport and food. Good governance of urban sustainability performance will require an efficient urban metabolism, facilitated through the delivery of more sustainable urban infrastructure.

\subsection{Three Horizons of Urban Sustainability Performance}

Measuring urban metabolic flows makes it possible to differentiate between three levels of green urbanism commitment: "green design", "sustainable development" and "regenerative urbanism". Each of these levels, or horizons, represents a step-change in urban planning innovation and systems integration. Horizon thinking is usually associated with business innovation to plan for future opportunities, its application to urban planning was first used by Newton [66]. We apply this approach to the three horizons of urban sustainability performance. Effectively, these notions correspond to three levels of efficiency in urban metabolism: green design has a lower ecological footprint than the usual extractive linear metabolism; sustainable development aims to be net zero in its footprint; however, regenerative cities demonstrate a circular metabolism that enables net positive outcomes $[58,62,67]$. Exemplars are provided to describe some real world examples of such regenerative urban systems. The three horizons are illustrated in Figure 2. 


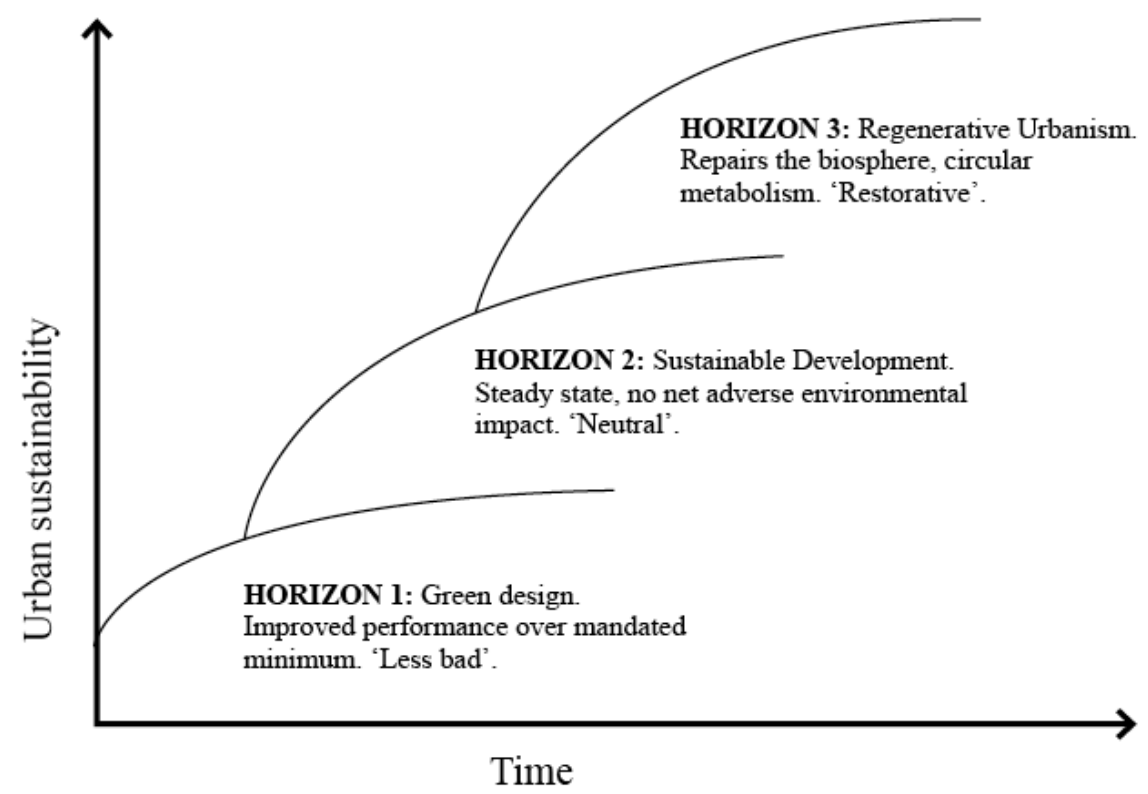

Figure 2. The three horizons of green urbanism.

Green development represents sustainability improvement upon the existing baseline required by local building codes or other statutory regulations. It is a "less bad" response to conventional (unsustainable) development. Typical improvements include energy and water demand reduction, resource efficiency measures and renewable or alternative technologies.

Sustainable development is defined by Brundtland [7] as "development that meets the needs of the present without compromising the ability of future generations to meet their own needs". Essentially, this notion is "neutral", sustaining the environment over time with no net adverse impact. This approach focuses upon sustainable city initiatives that seek to have no net impact such as zero carbon urban developments like BedZED [68]. However, in many urban locations the local environment is already greatly degraded, particularly in terms of ecosystems services, prompting commentators such as Woo to suggest "it is no longer enough to only look at sustainable development because the ability of future generations to meet their own needs is already compromised" [69]. The notion is however useful for defining a threshold below which the environment (or components of the environment) continue to degrade, and above which the environment regenerates.

Regenerative urbanism applies regenerative design [70-72] to the urban environment. It involves consciously repairing a degraded environment and actively improving the biosphere whilst providing for the integration of urban systems that provide for human needs. This approach actively seeks to repair and regenerate sustainability indicators associated with planetary boundaries at the local scale (e.g., GHG emissions, water, nutrient cycles, etc.) through every step in urban development. At its most effective a regenerative urbanism will deliver urban infrastructure that results in less emissions, reduced water demand, cleaner energy, local food production, waste recovery and so on.

In terms of these three innovation horizons, simple green design approaches to development are now commonplace, sustainable development is occasionally observed and regenerative design can only be described as emergent. Yet, often there is no clear definition between the urban sustainability performance of any given "green" development and a plethora of terms may be used to describe the outcome such as "eco-city", "sustainable city", "smart city", "low-carbon city", "resilient city" to name a few $[73,74]$. What is critically important is the consistent definition of performance metrics as measured through an urban metabolism model $[61,62,64,75,76]$. From a city planning perspective whether a development is conventional, green, sustainable or regenerative, planners will need to understand the relative potential of an area to be transformed and weaknesses that may be improved. 
The next section describes these three horizons in relation to energy (in terms of GHG emissions). It relates to decarbonizing cities and the role cities may play in implementing the Paris Agreement. A similar approach may be applied to any number of sustainability metrics including water, waste, food and biodiversity to measure and to understand how these elements are performing.

\subsection{The Three Urban Horizons in Relation to Decarbonizing Cities}

The three urban horizons can describe urban performance within a defined geographic area, at whatever scale, whether a plot, precinct or a whole city. Sustainable Development results from a steady state of basic resources [77] (e.g., net zero emissions, biodiversity). This steady state threshold forms a baseline below which urban sustainability improvements can be described as green design and above which can be called regenerative. Green design is less bad than conventional development (i.e., development that meets the minimum planning regulations), but ultimately still degrades the biosphere; whereas regenerative urbanism results in the net repair to one or more parts of the system.

To be regenerative in terms of climate mitigation, carbon dioxide equivalence $\left(\mathrm{CO}_{2}-\mathrm{e}\right)$ will need to be net negative, either within the subject area boundary or through offsets at another location. Methods for calculating $\mathrm{CO}_{2}-$ e are complicated and are subject to carbon accounting standards such as the greenhouse gas protocol [78].

Usually, it is more useful to think of sustainability implications from a precinct or city scale rather than an individual plot because greater efficiencies can be achieved through a combination of integral, on-site and precinct-wide infrastructure, such as renewable energy $[57,79,80]$. Where the aspiration is for low carbon development, shortfalls can be addressed through off-site supply. Higher densities with distributed renewable energy supply and shared infrastructure provision at the precinct or city scale offer co-locational advantages with cost per dwelling decreasing as densities increase [81].

Green design represents an improvement upon conventional performance; in relation to energy its key components may be represented as a triangle $[82,83]$ split into three sections as seen in Figure 3. The triangle base represents the major energy savings through demand management measures, i.e., less consumption; the middle band efficiency e.g., transport efficiency, heating and cooling efficiency, appliance efficiency; and the top of the triangle, renewable energy or other low carbon energy source e.g., photovoltaic panels. The triangle shape conceptualizes the relative emissions savings of each band with most of the effort and most of the GHG emission reductions met through demand management, leaving only a small need for renewable energy to meet local GHG reduction targets.

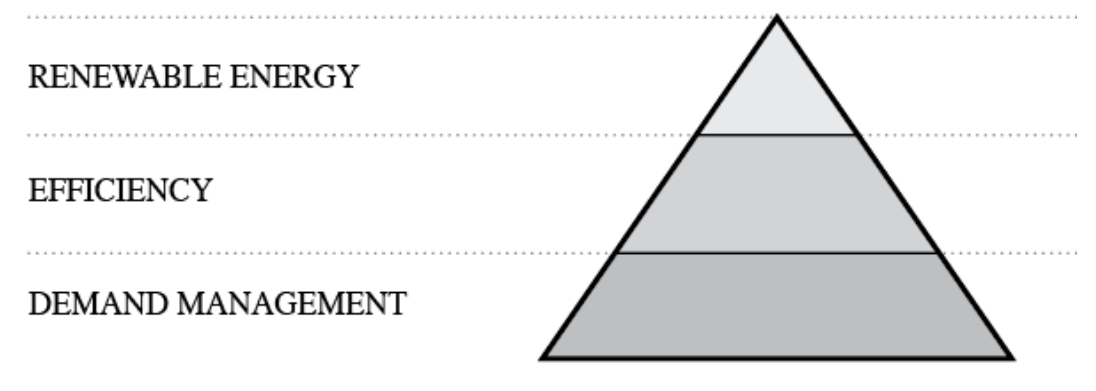

A. Green Design

Figure 3. Conceptual diagram of the carbon reduction elements of Green Design.

Sustainable Development, in the context of GHG, aims to be "carbon neutral"; this is typically achieved by increasing the renewable energy component until the renewables offset operational and embodied energy (see B in Figure 4).

The introduction of urban geoengineering techniques, that could perform 'third way' CDR functions would allow cities to go one step further by actively regenerating the Anthropocene. For example, urban geoengineering could remove GHG from the atmosphere as discussed in further detail 
below under the heading "CDR technology". We consider this a regenerative function, because, in addition to offsetting all embodied and operational energy, the urban geoengineering function reduces atmospheric $\mathrm{CO}_{2}$ to effectively mitigate climate change risk.

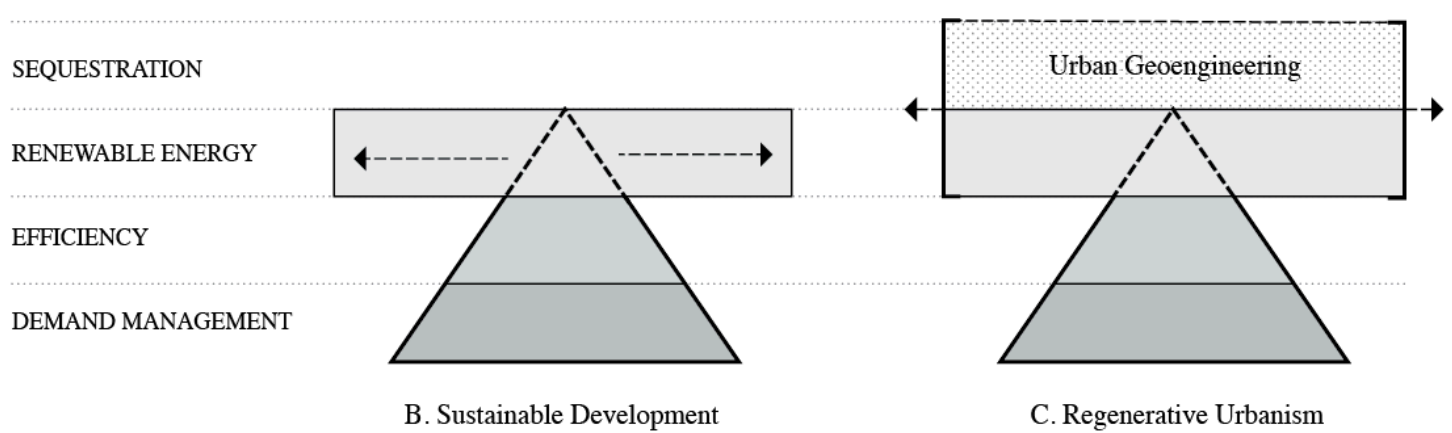

Figure 4. Conceptual diagram of the carbon reduction elements of Sustainable Development (B) and Regenerative Urbanism (C).

Considering diagram $\mathrm{C}$ in Figure 4, four distinct techniques can be used in a regenerative urbanism approach to reduce GHG including:

1 Structures that reduce energy demand and therefore reduce GHG emissions,

2 Operational efficiency measures that improve energy efficiency,

3 Renewable energy sources to displace GHG emitting fuels,

4 CDR techniques utilizing third way technology to actively remove GHG from the atmosphere (urban geoengineering).

\section{Structures that reduce GHG emission demand}

Examples of urban structural elements that reduce GHG emissions include:

- Urban growth boundaries for compact city footprints to reduce urban encroachment upon adjoining carbon sinks such as forested land, e.g., Portland, Oregon's urban growth boundary, a policy which has been in place since the 1970s [84];

- $\quad$ Targeted density increases that reduce energy needs for transport due to shorter distances between locations [21,33];

- $\quad$ Reduced embodied energy in materials [34,35];

- High thermal performance of buildings reducing heating and cooling energy demand $[82,83,85,86]$;

- Urban forest and biophilic strategies that shade habitable areas to regulate heat island effect and regulate microclimates reducing heating and cooling energy demand $[87,88]$.

\section{Operational efficiency measures that improve energy performance}

Examples of urban operational efficiencies include:

- Energy efficient appliances;

- Transport technology efficiencies;

- Utility technological efficiencies such as Trigeneration [89,90];

- $\quad$ Passive building design [91]. 


\section{Renewable energy sources}

Examples of urban and bioregional renewable energy sources include:

- Solar photovoltaics [80,92];

- $\quad$ Biofuels, biogas or combustible waste [93,94];

- Ground source, water source or geo-thermal energy $[95,96]$.

\section{CDR technology/urban geoengineering}

Urban geoengineering, in combination with renewable energy in a low demand and highly efficient urban environment, can turn cities into CDR machines, while at the same time reducing emissions at source.

A range of novel techniques can be applied to urban geoengineering including:

- Carbon negative construction such as:

- Carbon absorbing cement that takes $\mathrm{CO}_{2}$ from industrial waste and incorporates it into cement (e.g., Solidia cement) and carbon negative plastics that capture $\mathrm{CO}_{2}$ from the air (e.g., Newlight Technologies AirCarbon) [29]

○ "Energy Plus" buildings that generate more electricity than they consume thus offsetting other high carbon energy sources [82,97]

- Prefabricated low carbon housing from biogenic materials (e.g., cross laminated timber, straw composite) that effectively sequester carbon if the biogenic materials are harvested from plantation sources [98,99].

- Carbon negative landscaping using Serpentine rocks that, when crushed, absorb $\mathrm{CO}_{2}$ from the air [29];

- Carbon negative waste streams, such as biochar from combustible timber waste (e.g., from sources such as biogenic building material offcuts, forestry and agricultural waste) [29];

- Carbon negative industrial products, such as the industrial manufacturing of carbon nano fibres for many functions and carbon fibre replacing steel [29];

- Urban and bioregional forestry and biophilic urbanism to absorb carbon biomass [100-102].

\section{Regenerative Cities}

As modeling of urban metabolism, along with a general understanding of urban systems, improves, there is growing evidence that human settlements have large untapped sustainability potential. Not only may cities potentially have no net impact, but they may even become regenerative, not only in terms of energy, but also for water, food and biodiversity [66,103]. Each of these elements needs an understanding of urban stocks and flows, which can be provided through an urban metabolism analysis [76,104].

The ideal regenerative city (resulting from regenerative urbanism) would allow a settlement to:

- Create more energy than it needed.

- Use water sparingly with full recycling so it would not need to draw upon an external supply and enable regeneration of ground water systems and rivers.

- Regenerate natural systems in degraded areas to support biodiversity of a complexity similar to the pre-settlement bioregion's natural capacity.

- $\quad$ Reduce the scale and length of centralized infrastructure for energy, water and storm water infrastructure, and the embodied and operational energy required for this infrastructure. 
Regenerative design aims to eliminate waste by finding new uses for residual products by treating them as resources, e.g., waste food becomes compost thereby reducing the waste going into the environment (e.g., landfill) and in turn reducing the need to import fertilizers. In this way, urban material flows are optimized with the intent to create a circular urban metabolism $[58,62,64]$. By applying a regenerative design approach to urbanism cities can begin to perform a restorative role in the biosphere. The process requires local management of resources and will help build a local green economy as outlined in Newman and Jennings [58] and as is rapidly happening in Australia's solar economy as described by Newton and Newman [105] and Green and Newman [106].

The regenerative potential of a location will vary, and specific needs will be highly dependent upon the climate. In this respect, regenerative design represents a very different approach from the universally applied Modernist "International Style" that has dominated city planning for most of the past century [107]. Far from being a utopian dream, there are numerous emerging examples with a variety of governance systems, such as:

- West Village, University of California (UC), Davis-the largest net zero carbon development in the USA-created by UC Davis with the local government [108];

- White Gum Valley or WGV (Perth, Australia) — a net positive energy precinct based on solar and batteries, with zero waste and high water goals—created by the WA Government, Fremantle Council and Curtin University;

- The Peterborough Carbon Challenge (marketed as "Vista")—in 2012 the largest zero carbon development in the UK-led by the UK Government as a "Carbon Challenge" demonstration site and delivered through a public private partnership [109];

- Both Hammarby Sjöstad and the Royal Stockholm Seaport-created by the Swedish and Stockholm governments-are regenerative in energy and water as well as exhibiting extremely high recycling waste rates (enabled by automated vacuum waste collection streams);

- Vauban, Freiburg in Germany-with its net positive renewable energy system, dubbed the "greenest city in Europe"-led by a not-for-profit civic group with facilitation from the local government [110].

A regenerative design approach seeks not only to improve environmental impact from minimum statutory requirements, but also to restore degraded environments in terms of all material flows $[58,69,100]$, with particular emphasis upon energy, water and waste.

Preservation, restoration and biomimicry of natural systems can improve biodiversity when applied at scale, an approach known as biophilic urbanism [87,101]. Biophilic urbanism is demonstrated in Singapore where vegetation clearing and biodiversity loss have both been reversed through scientifically-based urban planting between, around and on buildings [111] (see Figures 5 and 6). The increase in urban biocapacity in Singapore, has led to an estimated 20\% increase in canopy cover from 1987 to 2007 . This has been driven by a biophilic urbanism policy requiring that high density urban areas embrace natural systems, by integrating vegetation into building facades, rooftops and other urban infrastructure [111]. The advantages are abundant, including CDR through biomass creation, biodiverse habitats, local food production and livability improvements including aesthetics and cooling microclimates.

There is a growing body of literature on the theory of regenerative design and regenerative cities documenting the feasibility of this approach as early innovators deliver demonstration projects $[58,70,112,113]$. Such changes can rapidly be mainstreamed and set off an exponential growth in regenerative urbanism. This can not only make human environmental impact in urban areas less bad, but can start to regenerate degraded environments so that urban areas shift from being an ecological burden to an ecological asset, opening the possibility for the geological record to demonstrate a reversal of the negative impacts of the Anthropocene. 


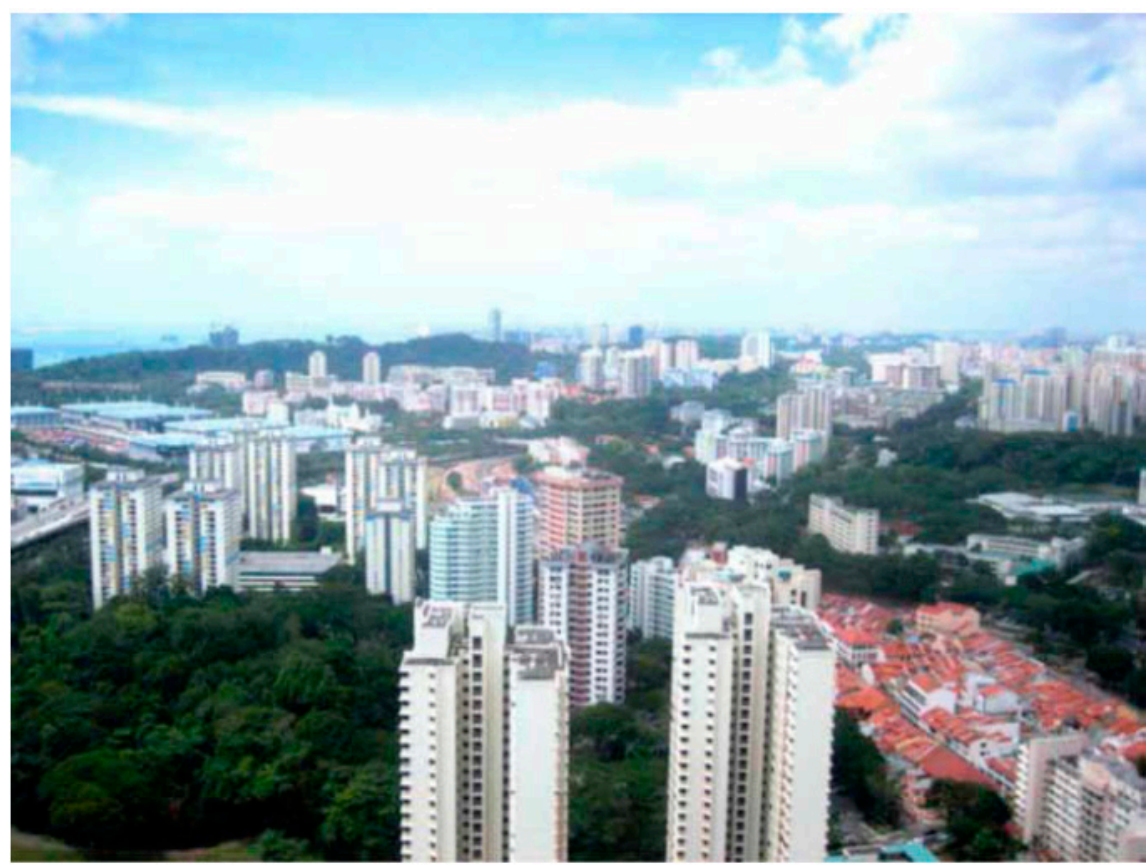

Figure 5. Singapore Garden City (source, Peter Newman).

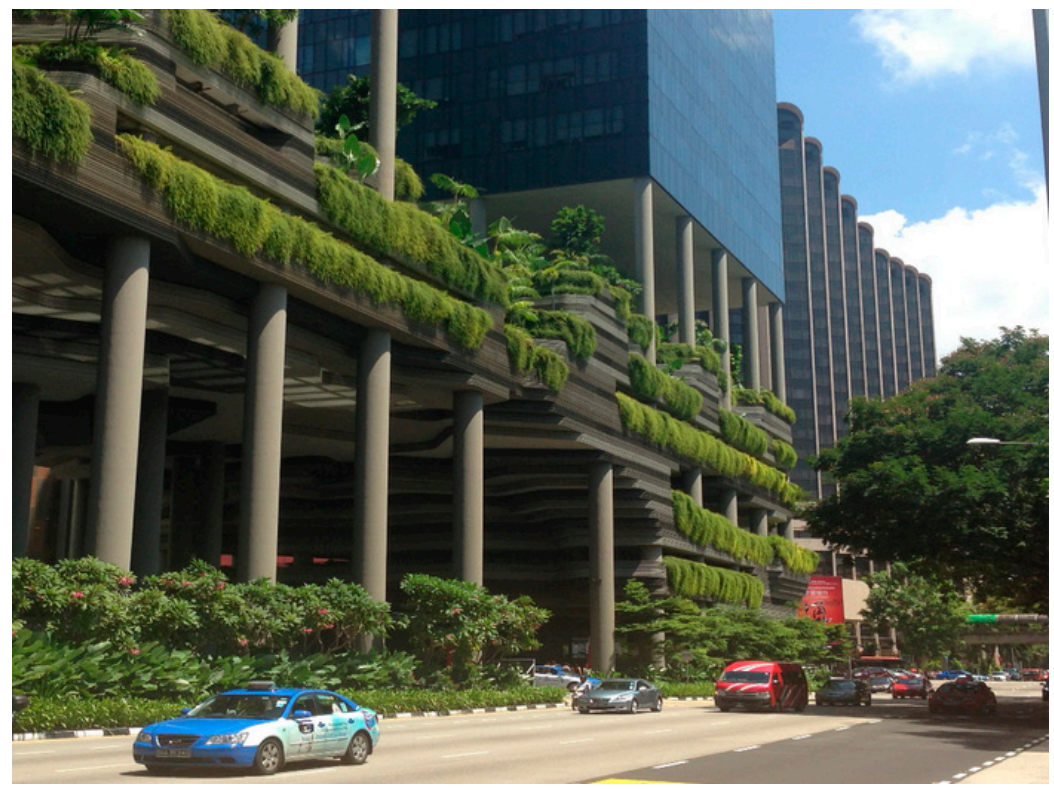

Figure 6. Park Royal Hotel in Singapore shows the city's commitment to biophilic urbanism, a component of the regenerative city agenda (source, Peter Newman).

\section{Conclusions}

The case for natural system-based geoengineering "silver bullets" is fraught with risks related to governance, ethics and technology, yet the need for viable climate change mitigation alternatives is growing. Most alternatives suggested to the world through IPCC are directed at national policies through global emissions reduction agreements such as the Paris Agreement. These top down policies are paralleled by bottom up approaches from grass roots groups and low carbon disruptive technologies being developed by industry. However, the biggest potential change agents can be found in the human resources that are brought together in cities as they can combine the top down regulatory and infrastructure power with the bottom up local concerns and disruptive technology demonstrations. 
Cities can drive massive small scale change with the cumulative potential for large scale urban geoengineering. Cities represent the arena in which change can be best managed and monitored and the greatest potential lies with developing nations where the highest rates of population growth and urbanization will occur. This growth will bring about new opportunities to either follow the consumptive pattern of the modernist developed world or take the disruptive technologies of the future and leap frog into demonstrating how cities can be urban geoengineers. This will require integrated urban planning at all scales from regional to the household as well as considerable modification of existing legislation, policies and codes driven by the highest levels of national government; but case studies are beginning to emerge that demonstrate this is not only feasible but cost effective [57].

Civilization in the Anthropocene is threatened by numerous planetary boundary transgressions including, but not limited to, climate change. However, consciousness is growing around human actions that can monitor and manage the global environment in relatively benign ways and even begin to regenerate the biosphere. For example, the Paris Agreement provides the mandate for this change and regenerative urbanism provides an approach to achieve the goals of the agreement. The driver and the evidence base exists, so the next step is for scientists and policy makers to work collaboratively on an evidence-based urban policy that delivers the social needs of the city, while actively applying urban geoengineering and regenerative approaches to reduce the ecological footprint beyond zero. The future is not written and it is still possible that the stewardship of our species in Earth's history can be aligned with a period of hope and renewal for the regenerated Anthropocene.

Acknowledgments: This research is funded by the CRC for Low Carbon Living Ltd. supported by the Cooperative Research Centres program, an Australian Government initiative.

Author Contributions: Giles Thomson conceived, researched and wrote the paper with input and additional contributions from Peter Newman based upon his original concepts.

Conflicts of Interest: The authors declare no conflict of interest.

\section{Abbreviations}

The following abbreviations are used in this manuscript:

$\begin{array}{ll}\text { CDR } & \text { Carbon Dioxide Removal } \\ \text { IPCC } & \text { International Panel on Climate Change } \\ \text { GHG } & \text { Green House Gas } \\ \text { GU } & \text { Green Urbanism } \\ \text { RU } & \text { Regenerative Urbanism } \\ \text { SRM } & \text { Solar Radiation Management }\end{array}$

\section{References}

1. Crutzen, P.J. Geology of mankind. Nature 2002, 415. [CrossRef] [PubMed]

2. Steffen, W.; Persson, Å.; Deutsch, L.; Zalasiewicz, J.; Williams, M.; Crumley, C.; Crutzen, P.; Folke, C.; Gordon, L.; Molina, M.; et al. The Anthropocene: From Global Change to Planetary Stewardship. Ambio 2011, 40, 739-761. [CrossRef] [PubMed]

3. Waters, C.N.; Zalasiewicz, J.; Summerhayes, C.; Barnosky, A.D.; Poirier, C.; Gałuszka, A.; Cearreta, A.; Edgeworth, M.; Ellis, E.C.; Ellis, M.; et al. The Anthropocene is functionally and stratigraphically distinct from the Holocene. Science 2016, 351, 137-147. [CrossRef] [PubMed]

4. Intergovernmental Panel on Climate Change (IPCC). Climate Change 2014: Mitigation of Climate Change. Contribution of Working Group III to the Fifth Assessment Report of the Intergovernmental Panel on Climate Change; Edenhofer, O., Pichs-Madruga, R., Sokona, Y., Farahani, E., Kadner, S., Seyboth, K., Adler, A., Baum, I., Bruuner, S., Eickemeier, P., et al., Eds.; Cambridge University Press: Cambridge, UK; New York, NY, USA, 2014; p. 1454.

5. Fink, J.H. Geoengineering Cities to Stabilise Climate. Proc. Inst. Civil Eng. Eng. Sustain. 2013, 166, $242-248$. [CrossRef] 
6. United Nations Department of Economic and Social Affairs Population Division. World Urbanization Prospects: The 2014 Revision, Highlights (ST/ESA/SER.A/352); United Nations: New York, NY, USA, 2014. Available online: http:/ / esa.un.org/unpd/wup/Highlights/WUP2014-Highlights.pdf (accessed on 17 October 2016).

7. World Commission on Environment and Development. Our Common Future; Oxford University Press: New York, NY, USA, 1987.

8. Newman, P.; Kenworthy, J. Cities and Automobile Dependence: An International Sourcebook; Gower Publishing Company: Aldershot, UK, 1989.

9. Intergovernmental Panel on Climate Change (IPCC). Summary for Policy Makers. In Climate Chang 2014: Impacts, Adapt Vulnerability. Contribution of Work Group II to the Fifth Assessment Report of the Intergovernmental Panel on Climate Change; Cambridge University Press: Cambridge, UK; New York, NY, USA, 2014; pp. 1-32.

10. Stern, N. The stern review on the economic effects of climate change. Popul. Dev. Rev. 2006, 32, 793-798.

11. United Nations Framework Convention on Climate Change (UNFCCC). Clean Development Mechanism Methodology Booklet; UNFCCC: New York, NY, USA, 2013.

12. Lynch, A.J.; Andreason, S.; Eisenman, T.; Robinson, J.; Steif, K.; Birch, E.L. Sustainable Urban Development Indicators for the United States; Penn Institute for Urban Research: Philadelphia, PA, USA, 2011.

13. United Nations. Adoption of the Paris Agreement. Available online: http://unfccc.int/resource/docs/2015/ cop21/eng/109r01.pdf (accessed on 17 October 2016).

14. Intergovernmental Panel on Climate Change (IPCC). Working Group III-Mitigation of Climate Change; IPCC: Geneva, Switzerland, 2014.

15. United Nations. Climate Action Now, Summary for Policymakers 2015; United Nations: New York, NY, USA, 2015.

16. Geels, F.W. Technological transitions as evolutionary reconfiguration processes: A multi-level perspective and a case-study. Res. Policy 2002, 31, 1257-1274. [CrossRef]

17. Geels, F.W. Ontologies, socio-technical transitions (to sustainability), and the multi-level perspective. Res. Policy 2010, 39, 495-510. [CrossRef]

18. Smith, A.; Voß, J.P.; Grin, J. Innovation studies and sustainability transitions: The allure of the multi-level perspective and its challenges. Res. Policy 2010, 39, 435-448. [CrossRef]

19. Girardet, H. Creating Regenerative Cities; Routledge: Abingdon, Oxon, 2015.

20. Droege, P. Urban Energy Transition: An Introduction; Elsevier Science: New York, NY, USA, 2008; p. 655.

21. Newman, P.; Kenworthy, J. Sustainability and Cities: Overcoming Automobile Dependence; Island Press: Washington, DC, USA, 1999.

22. Geels, F.W. The multi-level perspective on sustainability transitions: Responses to seven criticisms. Environ. Innov. Soc. Transit. 2011, 1, 24-40. [CrossRef]

23. Australian Public Service Commission. Tackling Wicked Problems: A Public Policy Perspective; Commonwealth of Australia: Canberra, Australia, 2007; p. 46.

24. Newton, P.W. Liveable and Sustainable? Socio-Technical Challenges for Twenty-First-Century Cities. J. Urban Technol. 2012, 19, 81-102. [CrossRef]

25. House of Commons Science and Technology Committee. The Regulation of Geoengineering; House of Commons Science and Technology Committee: London, UK, 2010.

26. National Academy of Science. Climate Intervention: Reflecting Sunlight to Cool Earth; National Academies Press: Washington, DC, USA, 2015.

27. University of Oxford. PRESS RELEASE: "Oxford Principles" Provide a Code of Conduct for Geoengineering Research; University of Oxford: Oxford, UK, 2011.

28. National Academy of Sciences. Climate Intervention: Carbon Dioxide Removal and Reliable Sequestration; National Academies Press: Washington, DC, USA, 2015.

29. Flannery, T. Atmosphere of Hope: Solutions to the Climate Crisis; Penguin Books Limited: London, UK, 2015.

30. Norgaard, R. Escaping Economism, Escaping the Econocene. In Economy of Sufficiency; Schniedewind, U., Santarius, T., Humburg, A., Eds.; Wuppertal Institute for Climate, Environment and Energy: Wuppertal, Germany, 2013; pp. 44-53.

31. United Nations Population Fund (UNFPA). The State of the world Population 2007: Unleashing the Potential of Urban Growth; UNFPA: New York, NY, USA, 2007.

32. Kenworthy, J. Total daily mobility patterns and their implications for forty-three global cities in 1995 and 2005. World Transp. Policy Pract. 2014, 20, 41-55. 
33. Kenworthy, J.; Laube, F. Millenium Cities Database for Sustainable Transport; International Association for Public Transport: Brussels, Belgium, 2001.

34. Gardner, H.; Newman, P. Reducing the Materials and Resource Intensity of the Built form in the Perth and Peel Regions; Curtin University Sustainability Policy (CUSP) Institute: Perth, Australia, 2013.

35. Newman, P.; Kenworthy, J. The End of Automobile Dependence: How Cities are Moving Beyond Car-Based Planning; Island Press: Washington, DC, USA, 2015.

36. United Nations. World Urbanization Prospects 2014: Highlights; United Nations: New York, NY, USA, 2014.

37. UN Habitat. Urbanization and Development Emerging Futures; World Cities Report 2016; United Nations Human Settlements Programme: Nairobi, Kenya, 2016.

38. Krockenberger, M. Population Growth in Australia; The Australia Institute: Canberra, Australia, 2015.

39. Newton, P.; Newman, P.; Glackin, S.; Trubka, R. Greening the Greyfields: Unlocking the Redevelopment Potential of the Middle Suburbs in Australian Cities. World Acad. Sci. Eng. Technol. 2012, 71, 658-677.

40. Delhagen, E.; McKearnan, S.; Nicholas, S.; Hamilton, B.; Neme, C.; Wang, E. Scaling up Building Energy Retrofitting in US Cities-A Resource Guide for Local Leaders; Living Cities: Washington, DC, USA; Institute for Sustainable Communities: Montpelier, VT, USA, 2009.

41. United Nations. A New Global Partnership: Eradicate Poverty and Transform Economies through Sustainable Development: The Report of the High-Level Panel of Eminent Persons on the Post-2015 Development Agenda; United Nations: New York, NY, USA, 2013.

42. Newman, P.; Beatley, T.; Boyer, H. Resilient Cities: Responding to Peak Oil and Climate Change; Island Press: Washington, DC, USA, 2009.

43. Beatley, T. Green Urbanism: Learning From European Cities; Island Press: Washington, DC, USA, 2012.

44. Beatley, T.; Newman, P. Green Urbanism Down Under: Learning from Sustainable Communities in Australia; Island Press: Washington, DC, USA, 2012.

45. C40 Cities. Available online: http://www.c40.org/ (accessed on 17 October 2016).

46. ICLEI. Low Carbon Cities. Available online: http://www.iclei.org/activities/agendas/low-carbon-city.html (accessed on 17 October 2016).

47. International Organization for Standardization (ISO). Sustainable Development of Communities-Indicators for City Services and Quality of Life; ISO: Geneva, Switzerland, 2014.

48. International Organization for Standardization (ISO). International Standard Sustainable Development in Communities-Management System for Sustainable Development; ISO: Geneva, Switzerland, 2016.

49. Rauland, V. Decarbonising Cities: Certifying Carbon Reduction in Urban Development; Curtin University: Perth, Australia, 2013.

50. Droege, P. 100\% Renewable Energy-And Beyond_For Cities; World Future Council: Hamburg, Germany, 2010.

51. Girardet, H. Cities People Planet: Liveable Cities for a Sustainable World; Wiley-Academy: Chichester, UK, 2004.

52. Rockström, J. A safe operating space for humanity. Nature 2009, 461, 472-475. [CrossRef] [PubMed]

53. Rockström, J.; Steffen, W.L.; Noone, K.; Persson, Å.; Chapin, F.S., III; Lambin, E.; Lenton, T.M.; Scheffer, M.; Folke, C.; Schellnhuber, H.; et al. Planetary Boundaries: Exploring the Safe Operating Space for Humanity. Ecol. Soc. 2009, 14, 32.

54. Steffen, W.; Richardson, K.; Rockström, J.; Cornell, S.E.; Fetzer, I.; Bennett, E.M.; Biggs, R.; Carpenter, S.R.; de Vries, W.; de Wit, C.A.; et al. Planetary boundaries: Guiding human development on a changing planet. Science 2015, 347. [CrossRef] [PubMed]

55. Birkeland, J. Positive Development: From Vicious Circles to Virtuous Cycles Through Built Environment Design; Earthscan: London, UK, 2008.

56. Cole, R.J. Net-zero and net-positive design: A question of value. Build. Res. Inf. 2015, 43, 1-6. [CrossRef]

57. Rauland, V.; Newman, P. Decarbonising Cities: Mainstreaming Low Carbon Urban Development; Springer: Cham, Switzerland, 2015.

58. Girardet, H. Regenerative Cities. Available online: www.worldfuturecouncil.org (accessed on 17 October 2016).

59. Newman, P.; Jennings, I. Cities as Sustainable Ecosystems: Principles and Practices; Island Press: Washington, DC, USA, 2008.

60. Baccini, P. A city's metabolism: Towards the sustainable development of urban systems. J. Urban Technol. 1997, 4, 27-39. [CrossRef]

61. Baccini, P.; Brunner, P.H. Metabolism of the Anthroposphere: Analysis, Evaluation, Design; MIT Press: Cambridge, MA, USA, 2012. 
62. Newman, P. Sustainability and cities: Extending the metabolism model. Landsc. Urban Plan. 1999, 44, 219-226. [CrossRef]

63. Kennedy, C.; Cuddihy, J.; Engel-yan, J. The Changing Metabolism of Cities. J. Ind. Ecol. 2007, 11, 43-59. [CrossRef]

64. Broto, V.C.; Allen, A.; Rapoport, E. Interdisciplinary Perspectives on Urban Metabolism. J. Ind. Ecol. 2012, 16, 851-861. [CrossRef]

65. Wolman, A. The Metabolism of Cities. Sci Am. 1965, 213, 179-190. [CrossRef] [PubMed]

66. Newton, P.W. Horizon 3 planning: Meshing liveability with sustainability. Environ. Plan. B Plan. Des. 2007, 34, 571-575. [CrossRef]

67. Newman, P.; Mason, A.; Gardner, H. Regenerative Cities; ARUP and Curtin University: Perth, Australia, 2012.

68. BioRegional. BedZED: Toolkit Part II A Practical Guide to Producing Affordable; BioRegional: London, UK, 2009.

69. Woo, F. Regenerative Urban Development; World Future Council: Hamburg, Germany, 2014.

70. Lyle, J.T. Regenerative Design for Sustainable Development; Wiley: New York, NY, USA, 1996.

71. Du Plessis, C. Towards a regenerative paradigm for the built environment. Build. Res. Inf. 2012, 40, 7-22. [CrossRef]

72. Hes, D.; du Plessis, C. Designing for Hope: Pathways to Regenerative Sustainability; Taylor \& Francis: Boca Raton, FL, USA, 2014.

73. De Jong, M.; Joss, S.; Schraven, D.; Zhan, C.; Weijnen, M. Sustainable-smart-resilient-low carbon-eco-knowledge cities; making sense of a multitude of concepts promoting sustainable urbanization. J. Clean. Prod. 2015, 109, 25-38. [CrossRef]

74. Joss, S. Eco-cities and Sustainable Urbanism. In International Encyclopedia of the Social and Behavioral Sciences, 2nd ed.; Wright, J., Ed.; Elsevier: Oxford, UK, 2015; Volume 6, pp. 829-837.

75. Kennedy, C.; Pincetl, S.; Bunje, P. The study of urban metabolism and its applications to urban planning and design. Environ. Pollut. 2011, 159, 1965-1973. [CrossRef] [PubMed]

76. Gandy, M. Rethinking urban metabolism: Water, space and the modern city. City 2004, 8, 363-379. [CrossRef]

77. Daly, H. The Steady-State Economy. In Sustainable Urban Development Reader; Wheeler, S.M., Beatley, T., Eds.; Taylor \& Francis: New York, NY, USA, 2014; pp. 47-52.

78. Greenhouse Gas Protocol. Available online: http://www.ghgprotocol.org/ (accessed on 17 October 2016).

79. Newton, P. Beyond Greenfields and Brownfields: The Challenge of Regenerating Australia's Greyfield Suburbs. Built Environ. 2010, 36, 1-53. [CrossRef]

80. Newton, P.; Newman, P. The geography of solar photovoltaics (PV) and a new low carbon urban transition theory. Sustainablity 2013, 5, 2537-2556. [CrossRef]

81. Newton, P. Regeneration: Tackling the Greyfields. In Creating Sustainable Precincts; Perinotto, T., Ed.; The Fifth Estate: Sydney, Australia, 2014; pp. 106-111. Available online: http:/ /evacoust.startlogic.com/TimeToyota. pdf (accessed on 17 October 2016).

82. Reidy, C.; Lederwasch, A.; Ison, N. Defining Zero Emission Buildings; Australian Sustainable Built Environment Council: Surry Hills, Australia, 2011.

83. Zero Carbon Hub. Defining a Fabric Energy Efficiency Standard for Zero Carbon Homes; Zero Carbon Hub: London, UK, 2009.

84. Nelson, A.C.; Moore, T. Assessing urban growth management. The case of Portland, Oregon, the USA's largest urban growth boundary. Land Use Policy 1993, 10, 293-302. [CrossRef]

85. Hyde, R.; Rajapaksha, U.; Rajapaksha, I.; Riain, M.O.; Silva, F. A Design Framework for Achieving Net Zero Energy Commercial Buildings. In Proceedings of the 46th Annual Conference of the Architectural Science Association (ASA/ANZAScA), Griffith University, Gold Coast, Australia, 14-16 November 2012.

86. Stulz, R.; Lütolf, T. What Would Be the Realities of Implementing the 2000 Watt Society in Our Communities? Available online: http://www.energy-cities.eu/IMG/pdf/imagine_session1_stulz_en.pdf (accessed on 17 October 2016).

87. Beatley, T. Biophilic Urbanism: Inviting Nature Back to Our Communities and Into our Lives. William Mary Environ. Law Policy Rev. 2009, 34, 209-238.

88. Davison, A.; Kirkpatrick, J. Re-inventing the Urban Forest: The Rise of Arboriculture in Australia. Urban Policy Res. 2013, 32, 145-162. [CrossRef]

89. Bunning, J.; Beattie, C.; Rauland, V.; Newman, P. Low-Carbon Sustainable Precincts: An Australian Perspective. Sustainability 2013, 5, 2305-2326. [CrossRef] 
90. UK Green Building Council; Zero Carbon Hub. Sustainable Community Infrastructure; UK Green Building Council: London, UK, 2010.

91. Green Building Council of Australia. A Decade of Green Building. Available online: https://www.gbca.org. au/uploads/170/34474/A_decade_of_green_building_.pdf (accessed on 17 October 2016).

92. Kost, C.; Schlegl, T.; Thomsen, J.; Nold, S.; Mayer, J. Levelized Cost of Electricity—Renewable Energies; Fraunhofer ISE: Freiburg, Germany, 2012.

93. GIZ; ICLEI. Operationalizing the Urban NEXUS: Towards Resource Efficient and Integrated Cities and Metripolitan Regions; GIZ: Eschborn, Germany; ICLEI: Bonn, Germany, 2014.

94. ClimateWorks Australia. Tracking Progress Towards a Low Carbon Economy. Available online: http:/ /www.climateworksaustralia.org/sites/default/files/documents/publications/climateworks_ tracking_progress_discussion_paper_nov2012.pdf (accessed on 17 October 2016).

95. Office of Energy. Renewable Energy Handbook 2010; Office of Energy: Perth, Australia, 2010.

96. Droege, P. 100\% Renewable: Energy Autonomy in Action; Routledge: London, UK, 2012.

97. Newton, P.W.; Tucker, S.N. Pathways to decarbonizing the housing sector: A scenario analysis. Build. Res. Inf. 2011, 39, 34-50. [CrossRef]

98. Acosta, M.S.; Mastrandrea, C.; Lima, J.T. Wood Technologies and Uses of Eucalyptus wood from Fast Grown Plantation for Solid Products. In Proceedings of the 51st International Convention of Society of Wood Science and Technology, Concepción, Chile, 10-12 November 2008.

99. Thompson, H.; Waugh, A. A Process Revealed; FUEL Publishing: London, UK, 2009.

100. Beatley, T.; Newman, P. Biophilic cities are sustainable, resilient cities. Sustainablity 2013, 5, 3328-3345. [CrossRef]

101. Kellert, S.R.; Heerwagen, J.; Mador, M. Biophilic Design: The Theory, Science and Practice of Bringing Buildings to Life; Wiley: New York, NY, USA, 2011.

102. Beatley, T. Biophilic Cities: Integrating Nature Into Urban Design and Planning; Island Press: Washington, DC, USA, 2011.

103. Girardet, H. Creating a Sustainable Adelaide. Available online: http://www.thinkers.sa.gov.au/lib/pdf/ Girardet_Report.pdf (accessed on 17 October 2016).

104. Pincetl, S.; Bunje, P.; Holmes, T. An expanded urban metabolism method: Toward a systems approach for assessing urban energy processes and causes. Landsc. Urban Plan. 2012, 107, 193-202. [CrossRef]

105. Newton, P.; Newman, P. Low Carbon Green Growth: Tracking Progress in Australia's Built Environment Industry Towards a Green Economy; Swinburne University of Technology: Melbourne, Australia; Curtin University: Bentley, Australia; The Green Building Council of Australia: Sydney, Australia, 2013.

106. Green, J.; Newman, P. Citizen Utilities: The Emerging Power Paradigm. A Case Study in Perth, Australia. Energy Policy 2016, in press.

107. Thomson, G.; Newman, P. Urban Fabric and Urban Footprint. Resour. Conserv. Recycl. 2017, in press.

108. UC Davis. UC Davis West Village, Energy Initiative Annual Report 2013-2014; UC Davis: Davis, CA, USA, 2014.

109. English Partnerships. Carbon Challenge: Standard Brief. Department of Communities and Local Government: London, UK, 2007.

110. Scheurer, J.; Newman, P. Vauban: A European Model Bridging the Green and Brown Agendas. Available online: www.unhabitat.org/grhs/2009 (accessed on 17 October 2016).

111. Newman, P. Biophilic urbanism: A case study on Singapore. Aust. Plan. 2014, 51, 47-65. [CrossRef]

112. Du Plessis, C.; Brandon, P. An ecological worldview as basis for a regenerative sustainability paradigm for the built environment. J. Clean. Prod. 2014, 109, 53-62. [CrossRef]

113. Cole, R.J. Transitioning from green to regenerative design. Build. Res. Inf. 2012, 40, 39-53. [CrossRef]

(c) 2016 by the authors; licensee MDPI, Basel, Switzerland. This article is an open access article distributed under the terms and conditions of the Creative Commons Attribution (CC-BY) license (http://creativecommons.org/licenses/by/4.0/). 